\title{
Corporate Social Responsibility (CSR): An Elixir for Socioeconomic Development in Nigeria
}

\author{
Sunday Israel Akinde
}

\begin{abstract}
Nigeria appears too slow in harnessing domestic resources towards meeting her socioeconomic needs. However, CSR has been found in several contexts as important means of realizing much-needed expectations of development. Nigeria is currently at the level of perceiving CSR merely as one-off philanthropic thing focusing merely on environmental protection. This study employs various means such as success stories of others, methods adopted for realization of vibrant CSR initiative in their own experience, and some time-tested examples of road map towards international best practices in order to arouse the curiosity of policy makers in Nigeria. The study identified certain structural- functional elements working in tandem for effective realization of CSR in Nigeria. These include Synergy of CSR and Corporate Governance (CG), a viable CSR organization, and institutionalization or culture of monitoring and control. Policy measures recommended include creating CSR into an agency or commission for effective take-off.
\end{abstract}

Index Terms - Corporate Governance (CG); CSR; Socioeconomic; Structural functionalism.

\section{INTRODUCTION}

Governments in Nigeria federal, state and local have not fully realized the important impact and tremendous contributions that corporate social responsibility could make in their socioeconomic development trajectories [1], [2]. Much emphasis has been laid on annual budgetary rituals leaving out what additions could be made through this avenue. CRS has been viewed as a sustainable economic model which positively impacts not only corporate entities and their stakeholders but host communities where such entities operate. CSR is a business strategy that positively boosts the image of the firm, shores up its goodwill and opens up vistas of clientele in times to come. CRS simply says that organizations doing business in a place create an enabling environment within their business locality thereby making life more meaningful to its business community, inhabitants and reaping the benefits of same in the long run. It is a business strategy that allows both ethical and legal reasoning to bear on corporate activities in the drive towards profit-making, though profit-making is not its primary aim. The main purpose of this paper is making both the government and the corporate organizations more alive to their responsibilities thereby increasing political capacity to garner needed resources towards provision of social good.

In Nigeria as in some other developing countries, corporate organizations have not been living up to expectations in their understanding and reactions towards

Published on August 24, 2020.

Sunday Israel Akinde, Adekunle Ajasin University, Nigeria.

(corresponding e-mail: akinsunday ${ }^{\circledR}$ gmail.com) efforts at making them more socially responsible [3]. Therefore, their responses to such issues have been that of necessity as against exercise of will and readiness. That may be blamed on the fact that the concept is yet a novelty in most developing societies. Visser and Tohult [4] assert that CRS in Africa is still in its infancy. That notwithstanding, there are enormous challenges faced by Nigeria as in most African countries that direct government efforts may be inadequate to fully cater for. There are acute socioeconomic challenges begging for attention in these countries. Socioeconomic development indicates improvement in the material conditions of life of a people which enables them to lead a meaningful life and adequately meeting such basic needs of life as food, shelter, education and good health This is, in addition to its economic element, akin to human development as often conceptualized by the United Nations Development Report [5] using the measure of Human Development Index (HDI) in making comparison among levels of human development across nations. HDI measures the three basic dimensions of human development - a long and healthy life, knowledge and a decent standard of living [5].

The current state of human development profile in Nigeria is of crucial concern. In 2019 [6] for example, the UNDR showed that Nigeria's Life Expectancy at Birth (LEB) was 53.4 years, 5.2 mean years of schooling, and 124 deaths per 1000 live births. Comparing that with figures from some sub-Saharan African nations and elsewhere, the difference is clear. For example, LEB in Mauritius is 74.7, 63.8 in Ghana, 72.7 in Libya and 75.5 in the Latin American country of Brazil. The absolute HDI of 0.534 for the country in relation to some other developing countries is considerably low. For example, in Singapore, LEB is 0.935 , in Qatar, it is 0.948 , and for Malaysia, it is 0.904 , to mention just a few of them. The developing countries above are grouped among countries with very high HDI of 0.800 and above, while Nigeria is grouped among those with low HDI of 0.550 and below. This is because the closer a society is to $1($ One), the higher the level of human development.

Economic development in Nigeria has been problematic due to mismanagement, financial profligacy, endemic corruption and wholesale looting, weak state syndrome, to mention just a few. The country is blessed with unquantifiable endowment of human and material mineral resources begging for exploitation without adequate success Poverty which is an index of economic woe is widespread. The situation is both disheartening and chattering considering World Bank's remark [8] on poverty in Nigeria in a report titled, "Nigeria: poverty in the midst of plenty: the challenge of growth with inclusion, as far back as 1996 The report further yelled that "the per capita income in 
Nigeria today (1996, after 36 years post-independence) is around the same level as it was in 1970, despite the fact that the country earned over $\$ 200$ billion in the last 25 years from the exploitation of oil resources"[7]. The pervasiveness of poverty is expressed during national elections in the country as foodstuffs, ridiculous cash amounts, and other material items become crucially important as bait to woo voters. Most elections are won on the basis of highest bidder negotiation even at the eve of election. Politicians keep a retinue of salaried thugs who are ready to perpetrate mayhem at the slightest dangle of cash carrots. After the 2009 economic melt-down, the economy was diversified with agriculture and telecommunication showing promises of economic bailout. Ever since, the growth in these sectors have not solved food problem in the least while over $62 \%$ of about 180 million people still live in extreme poverty [8].

The economic development indicates the capacity of a people to create values leading to material resource transformations that result in productivity and distribution of goods and services needed by the people for appropriate standard of living. Taken together, socioeconomic aspect of life inextricably links [9] the idea of social development to the idea of economic and material advancement of human society [10]. Therefore, socioeconomic development is the process of social and economic transformations resulting in the formation and implementation of social and economic initiatives towards bringing about sustained improvement in standard of living among the citizenry. Hence, the key sectors of the economy such as human capital, technological innovation, GDP, life expectancy, literacy, and poverty and employment levels have generally been viewed as in a state of crises when they are not able to meet social expectations. With concerted efforts, part of these problems could be solved if expected accruals through vibrant CSR operation are well managed.

The cost of deficit in socioeconomic development bears heavy weight on governments that oftentimes the United Nations annually role out statistics in order to create awareness on both country and at regional levels with a view to sending warning signals regarding its deleterious effects should the reported situation persists. Studies are initiated from time to time bordering on state of socioeconomic profile of nations in order to flesh out global issues of concern to countries [11]. At times, timelines are declared on certain global issues which serve as benchmark on international social and economic best practices that member states are expected to adhere to as minimum standards [12]. Some international foundations and private development agencies are involved in various socioeconomic sensitization and advocacy in some countries and regions more particularly in areas of maternal and childhood health, and that of the general population. In fact, by extension, Bristol and Tisdell [13] argue that it is not only socioeconomic development policies that are made increasingly popular among the globalized businesses; but that firms are using CSR in order to increase the welfare of human resources.

Corporate social responsibility has delivered in several countries like China, India, and scores of other nations. For example, China is reported as a country where "CRS is booming due to government increasing controls and support aimed at making the enterprises more responsible"[14]. The CRS situation in China is such that companies are in competition over CRS activities in order not to be outmatched by others [15]. China's Representative for the United Nations Global Compact and a member of the 2015 intake of World Economic Forum (WEF) Young Global Leaders once remarked that:

CSR is embedded in corporate policies and actions through respecting and protecting human rights, safeguarding the well-being of workers and communities, protecting the environment, and eliminating corruption through good governance. It is key for companies to strategically integrate environmental, social and governance issues into its core business and decisionmaking processes, which goes far beyond legal compliance and philanthropy. However, perhaps more than their competitors, many Chinese companies view their futures as inextricably linked to their CSR performance and have begun viewing it as a potential competitive edge [16].

In India, CRS is rapidly growing being strengthened by Gandhi's philanthropic philosophy that caters for the needy in several areas of human endeavours. The initiative supports the government to facilitate production of public goods to the citizens [17]. To stress the link between CG and CSR, Balch [17] further states that "those who believe CSR needs to be embedded through the whole business, not just philanthropy, argue that companies must go further".

Many studies have investigated the various critical roles of maintaining a vibrant CSR system in several societies by clearing away certain development antinomies from the society such as corruption [18], [19]. Some studies have mentioned that certain policies of government aimed at making business organizations more responsible in the country are harsh. This was expressed by Mordi et al. [20] against the proposed CSR bill pending before the national assembly in Nigeria. Furthermore, research on CRS in Africa has dwelt much on ethics [21], lack of CSR reporting practice and accountability and the need to tackle weak public service delivery [22], [23] in key sectors such as healthcare and education, however, adequate attention has not yet been focused on creating viable structures for enhancing the socioeconomic aspect of governance thereby making CSR an important elixir for human development. At times, while these structures appear to be available, they are not institutionalized as an operational guide for CSR realization. Hence, this study adopts a composite approach in CRS development in Nigeria by emphasizing the need for codification of appropriate structures required for effective administration of vibrant CRS policy in the country.

\section{StRUCTURAL FUnCtiOnALIST EXPLANATION OF SOCIOECONOMIC DEVELOPMENT IN THE CONTEXT OF CSR}

When various parts of a society are viewed as dependent and interrelated, they exert enormous effect on the corporate existence of the social entity. Various components of a society play designated roles that make for proper functioning of the system as a whole [24]. Radcliff-Brown [24], the father of British structural functionalism theorized that societies comprise of many structures which possess norms that enable members of society to participate in the 
affairs of society for the purpose of social cohesion. The various structures that are formed by social relations among people are oriented towards the stability of society. With his extensive studies of native institutions, Radcliff-brown drew several correspondences between organs of human body and various parts of society thus zero-in on the importance of institutions and social customs in the maintenance of societal stability. Functioning of each part of the system is also treated by Herbert Spencer [25] in which he drew attention to analogy of the human body with emphasis that the contribution made by each organ of the body is necessary for proper maintenance of the entire human body.

In the same way, CSR as a structural component in the economic institution of society, functions to add support towards the building of socioeconomic structure of society. Just like any other institutions of society contributes its quota towards the development of the entire society, so are the contributions made by CSR in building the socioeconomic edifice of society. According to Vincent [26] structural functional stresses the formal ordering of parts and their dependent relationship towards the maintenance of the existential needs of the entire social system. Although this approach lacks the inbuilt mechanism for explaining internal system conflict and pathological cases such as corruption, it stresses that the structure of any patterned social practice is the part it plays in the maintenance of the whole social system. CRS is expected as unit in the economic structure of society performing the function of contributing towards the maintenance of the entire social system. As structural functional analysis covers issues such as change and stability in the system, so is the socioeconomic sphere through the necessary inputs from the CRS and outputs from the socioeconomic substructure to the entire social system, changes in the social system are counter-balanced. This helps the system by saving it from collapse.

Productive activities especially mining by extractive industries impact much on the environment. This must be mitigated by commensurate returns on the environment by way of CRS inputs in order to enhance the sustainability of the operating environment. This is equally an ethical issue that provokes human right debate. It is the functional contributions by way of investing and reinvesting into the system that ensures the stability of the system. The socioeconomic possibility engendered through committed contributions from CSR [27] is employed for the purposes of sustaining the environment and the multiples of stakeholders involved. The social consciousness and awareness of the role being played by CSR will go a long way for the overall benefit of the entire system. This understanding would marshal necessary efforts towards ensuring that no stone is left unturned in the process of actualizing the goal of making the CRS a reality.

This is the practice in South Africa. As CSR is viewed as an all-encompassing issue built around the concept of sustainable development, it has become a must for businesses in South Africa in order to drive change and support sustainability. In 1993, the Institute of Directors in Southern Africa [28] appointed the retired Supreme Court judge, Mervyn E. King to chair a committee on corporate governance. The committee headed by King, referred to as
King Committee on Corporate Governance (KRGC) released its first report (King 1 Report) on corporate governance in 1994. Based on improvements and series of reforms, King II Report was launched in 2002, King III in 2009 and current King Report IV came into force in 2017. The 4th KRGC was an enlarged version of the earlier reports by KRCG on corporate governance with far-reaching provisions and principles for business including the NGOs in South Africa. KRCG is aimed at making community development part of corporate governance culture in South Africa, and not just for the preservation of natural resources, as it is being perceived at present in Nigeria. It was conceived as a means of developing the economy, environment and the community at large. More particularly, the Fourth Report was focused among others on "ethical and effective leadership; company's role and responsibility in society, sustainable development and stakeholder inclusivity and responsiveness....currently, King IV serves to foster greater transparency in business... holds an organization's governing body and stakeholders accountable for their decisions while its (King 4) compliance has become compulsory for all businesses listed on the Johannesburg Stock Exchange" [28].

\section{CSR PRACTICE IN NIGERIA}

As earlier mentioned, CSR is relatively new in most developing countries including Nigeria. CSR has been in practice since 1995 in Europe and America, but later in Africa. According to Amaeshi et al. [29], CSR activities began with the operations of the Multi-National Companies (MNCs) in Nigeria especially in the oil sector. Firms in Nigeria both indigenous and foreign practiced CSR as philanthropy addressing the socioeconomic challenges in the country. Continuity and commitment to the activities are mainly expressed through palliative measures to maintain some measures of public relations with host communities. Such measures include grant of education scholarships to indigenes, construction of school classrooms, feeder-road projects and installation of pipe-borne water facilities. Sometimes, it is reported [29] that some of such activities did not meet the expectations of the community concerned and as such soon became abandoned projects.

Laws that seem to possess the semblance of CSR were basically meant to protect the environment instead of the basic reasons of responsibility, sustainability and socioeconomic drive. For example, such laws include the Criminal Code Act, Oil in Navigable Waters Act, National Oil Spill Detection and Response Agency (Establishment) 2006, National Environmental Standards and Regulations Enforcement Agency Establishing Act 2007 (NASREA), Regional and International Legal Framework for the Protection of the Environment against Environmental Crimes [30], and a host of others. These laws are yet to be harmonized as they are scattered bits though they had been passed by some relevant authorities. CSR is not perceived or practised as part of corporate governance neither as content of responsible and sustainable business model. CSR events are mainly concentrated around the MNCs and a few blue chip companies.

Part of what may be called a sensitization and wakeup 
call to business in Nigeria is when the Federal Government introduced the $2 \%$ education tax fund from to be deducted from all profits made by relevant organizations (before tax) in Nigeria in 1993, but took effect in 1994. This was borne out of the fact that the ethical justification of business activities in their operating environment has not been given adequate attention by firms. At present, most actions of firms in respect of CSR are mainly focused on philanthropy. For example, most establishments both indigenous and foreign are yet to factor in the element of CSR neither in their product brands nor as part of their corporate governance objectives. Most big concerns including government parastatals are hardly responsible for some of their activities neither are they meticulous in carrying out the due diligence on Environment Assessment Impact (EAI) studies of some of their operations. The current operation of CSR in the country on the part of both the government and business needs to be fully engaged by relevant NGOs for responsible actions. This has become necessary as efforts towards socioeconomic support are yet to be realized.

\section{Structures For The Establishment OF A Vibrant CSR IN NIGERIA}

Building a virile CSR requires the following among others:

1. Synergy between Corporate Governance and CSR Structure

2. CSR Organization.

3. Institutionalization or Culture of Monitoring and Control.

\section{A. Synergy between Corporate Governance and CSR Structure}

Corporate Governance (CG) as a system by which businesses are directed and controlled, ensures that the board of directors agree at the onset not only on the statutory requirements for the establishment, but the direction of CSR and its contents. As decisions of top management are passed down the communication lines, the objective of the establishment with regard to CSR is also circulated. This possesses the capacity to socialize organization members and stakeholders on the importance of CSR, thus popularizing the principles of responsibility and sustainable behavior. Building the synergy between CSR and CG helps to develop innovative processes and services within core business areas, which will bring about improved environmental protection and positive improvement in the socioeconomic lives of citizens [31]. Besides, The European Commission [27] once remarked that "CSR can contribute to sustainable development by generating accountable and responsible business behavior thereby contributing to employability and job creation".

CSR is not only meant for ensuring ethical concern on the business community, it touches on the various stakeholders which include employees of the establishment [32], establishment officers, shareholders, suppliers, and the host community. CG is manned by directors who take important decisions on the business. As representatives of the company's shareholders, they take important decisions on ethical and environmental concerns which shareholders hold as priority areas [33]. Among others, they undertake risk management activities especially on issues that bother on sound ethical and environment practice which affect the financial interests and public image of the company. Corporate governance practice encourages firms to ensure sound ethical principles and dogged adherence to laid down rules and obligations for actualizing corporate goals. In pursuit of this, CSR becomes an important area for top management to watch in order to maintain the goodwill of the organization. Maintenance of sound human right practice, employee relations and environmental best practices require well-monitored corporate governance principles [34].

Under CG mechanism, firms are not encouraged only to promote ethics, fairness, transparency, and accountability in all their dealings, but to continue generating profits while maintaining the highest standards of governance internally as well.

In certain quarters, CSR is required as part of CG at national, regional and international levels for the purpose of maintaining effectiveness and international best practices. There are institutions set up for the purpose of making CG responsible for sustainable business environment through CSR. For example, the case of the International Institute for Sustainable Development (IISD) is well documented [31]. This is an institution of the Canadian International Development Agency (CIDA). IISD is a working Guide for promoting "policy recommendations on international trade and investment, economic policy, climate change and energy, measurement and assessment, and sustainable natural resources" [31]. Its central focus is to make CSR an integral part of the new business model. The Guide is premised upon the philosophy that "businesses are an integral part of the communities in which they operate" [31].

In the same vein, the EU developed a Strategy to enhance workability of CSR among member nations. The Guide, European Commission Strategy on CSR, contains how EU defines CSR and its guidelines and principles on establishment of CSR. The Commission issues Environmental Initiatives for Businesses referred to as EU's Eco-Management and Audit Scheme (EMAS). Firms are required to be EMAS compliant. For coverage, firms must have met certain conditions contingent on CSR. After EMAS certification is issued, its sustenance rests upon continued compliance with certain environmental and product requirements. Furthermore, organizations in certain quarters are required to build in CRS policy in their CG thus enhancing the credit rating of business [35]. Credit rating of business is a practice in which the rating agency qualitatively and quantitatively assesses a firm or government organization on ability to pay back the debt and the probability of default. Rating agencies disclose their evaluation to investors in order to indicate such decisions in their corporate objectives.

Some other institutions demanding CG reflecting CSR in their operations include the following:

- the OECD Guidelines for Multinational Enterprises CSR enforcement instrument of EU [36],

- the International Labor Organization Tripartite Declaration of Principles concerning Multinational Enterprises and Social Policy - CSR enforcement of ILO 
[37].

- the ISO 26000 Guidance Standard on Social Responsibility - An international CSR enforcement instrument [38].

- the United Nations Guiding Principles on Business and Human Rights - CSR enforcement of the UN [39];

and The United Nations Global Compact - CSR enforcement instrument of the $\mathrm{UN}$ as well [40].

\section{B. CSR Organization}

A new CSR will take into account a restructuring of the entire system of CSR that will make the policy stronger than what it is at present. The CSR should be institutionalized as an agency or commission. As an agency or commission, charged with mission or responsibility, the body will report directly, not to a supervising ministry where bureaucratic bottlenecks will kill vibrancy but the president himself, for the purpose of effectiveness. Under it, all relevant laws and various strands of regulations are harmonized towards effective operations of CSR. The law establishing CSR as an agency or commission is enacted. All activities of CSR are to be fully regulated with appropriate legislations. Sanctions and rewards for compliance are to be codified for the purpose easy reference by legal authorities and other enforcement agencies. The legal structure of CSR is tuned towards international best practices and current in the formulation of relevant principles and regulations in order to aid enforcement. The laws are reviewed periodically to reflect new trends while adherence to its provisions is manned by people of impeccable character and patriotic zeal.

\section{Institution or Culture of Effective Monitoring and Control}

Issues bothering on assessment of impact of business on the environment and ethics reflecting good consideration in respect of human rights, are to be subject of constant monitoring and control. To this end, all relevant agencies work in tandem for the singular purpose of making firms socially responsible and ensuring sustainability of the environment. Apart from CSR created to an agency or commission, roles of all relevant agencies and ministries are well outlined in order to avoid overlapping of functions and enhance efficiency. An implementation guide or code of conduct relating to sustainability is formulated and doggedly monitored for effective regular checkups and control. As part of monitoring and control of firms, firms are to reflect CSR activities in their annual reports not as a window dressing ritual, but as honest component of their annual activities. Inspection tours and consistent reporting are built into the monitoring in order to ensure on-spot assessment of activities and projects on the environment.

\section{CONCLUSION AND POLICY RECOMMENDATIONS}

This study has demonstrated the inertia of the Nigerian state as far as CSR activity is concerned. Issues of concern to the perennial socioeconomic challenges in the nation have also been fleshed out, most of which are yet to be addressed. Urgent actions are needed in effective formalization and contextualization of CSR in certain areas such as building synergy between CRS and corporate governing principles in business; and including Corporate and Allied Matters Commission as part of requirements for business registration of big concerns in Nigeria. The new CSR should demand corporate organizations built into their corporate processes the consciousness and implementation of CSR initiative as a structure in the corporate planning instead of one-off thing as it is being done at present. Nigeria can seek the membership of some of the above-mentioned CSR enforcement international agencies for effective CSR operations as most of the MNCs are also part of the organizations. More urgently is the need for the creation of CSR to either an agency or commission as earlier suggested for the purpose of effectiveness. All these will contribute towards effective realization of the goal of CSR for sustainability and socioeconomic support in Nigeria.

\section{REFERENCES}

[1] Sen, Rishita. 2017. "Social Responsibility with Socio-Economic Development". International Journal of Management, IT \& Engineering Vol. 7 (6): 119-124.

[2] Krypa, A. Nada. 2017. "Social economic development and the human resources management". Academic Journal of Interdisciplinary Studies, 6 (1): 73-76.

[3] Jamali, Dima, Lund-Thomsen, Peter, and Khara Navjote. 2017. "CSR Institutionalized Myths in Developing Countries: An Imminent Threat of Selective Decoupling". Business \& Society, 56 (3): 454-486.

[4] Visser, Wayne and Tolhurst, Nick. 2010. The World Guide to CSR: A Country-by-Country Analysis of Corporate Sustainability and Responsibility. Sheffield: Greenleaf.

[5] Human Development Report (2018) - "Human Development Indices and Indicators"(PDF). HDRO (Human Development Report Office) United Nations Development https://www.igi-global.com/ Accessed 13 March, 2020.

[6] United Nations Global Compact. 2000. The Ten Principles of the UN Global Compact, New York: United Nations. Available at: http://www.globalcompact.org.uk/> [Accessed 21 March 2020].

[7] World Bank. "Nigeria - Poverty in the midst of plenty: The challenge of growth with inclusion: a World Bank poverty assessment (English)". The World Bank Group, 1996, http://documents.worldbank.org/curated/en/582991468759320261/Ni geria-Poverty-in-the-midst-of-plenty-the-challenge-of-growth-withinclusion-a-World-Bank-poverty-assessment. Accessed 12 March 2020.

[8] The World Factbook 2020. Nigeria Economy 2020, Langley, Virginia: Central Intelligence Agency, 2020 https://theodora.com/wfbcurrent/nigeria/nigeria economy.html.

[9] Basiago, Andrew, D. 1999. Economic, social, and environmental sustainability in development theory and urban planning practice, CA: Chatsworth.

[10] Miller, Grant. and Babiarz, Kimberly, S. 2016. "Family Planning Program Effects: Evidence from Microdata". Population and Development Review 42: 7-26.

[11] McLanahan, Sara and Percheski. Christine. 2008. "Family structure and the reproduction of Inequalities". Annual Review of Sociology. 34:257-276.

[12] Human Development Report (2016). Human Development for Everyone, New York: UNDP.

[13] Bristol, Trammell, L. and Tisdell, Elizabeth Jean. 2010. "Leveraging diversity through career development: Social and cultural capital among African-American managers". International Journal of Human Resources Development and Management, 10(3): 224-238.

[14] Tian, Xiaowen and Slocum, John. W. 2016. "Managing Corporate Social Responsibility in China”. Organizational Dynamics 45 (1): 3946.

[15] Li, Kun, Khalil Nasrin R. and Cheng, Weiquan. 2019. "Corporate Social Responsibility Practices in China: Trends, Context, and Impact on Company Performance". Sustainability 11(2): 1-19.

[16] Liu, Meng. 2015. Is corporate social responsibility China's secret weapon? Geneva: World Economic Forum.

[17] Balch, Oliver. 2016. "Indian law requires companies to give $2 \%$ of profits to charity, Is it working?" The Guardian.Com, (https://www.theguardian.com/, April 5, 2016.). 
[18] Carr, I. and Outhwaite, O. 2014. "Controlling through corporate social responsibility and corporate governance: Theory and practice". Journal of Corporate Law Studies, 11(2): 299-339.

[19] Loch, Paul. and Lumumba, Otiendo. 2014. Corruption: The bane of Africa. Pp. 17-46 in Corruption in Africa: A Threat to Justice and Sustainable Peace, edited by Elizabeth Nduku and John Tenamwenye. Geneva: Globethics.net.

[20] Mordi, Chima, Opeyemi, Iroye. S., Tonbara, Mordi and Ojo, Stella. 2012. "Corporate Social Responsibility and the Legal Regulation in Nigeria". Economic Insights - Trends and Challenges 1(2): 16-22.

[21] Nwagbara, Uzoechi and Ugwoji, Chigozie A. 2015. "Corporate governance, CSR reporting and accountability: The case of Nigeria". Economic Insights Trends and Challenges, Vol. IV(LXVII) (1), 77 84. Online at: http://www.iisd.org/pdf/2007/csr_guide.pdf (Accessed: 8 April. 2020).

[22] Igbuzor, Otive. 2015. "Public Service Quality, Administration Reform The Guardian Sunday Magazine, March 22, 2015 https://guardian.ng/wp-

content/uploads/headlines/Sunday\%20Magazine_51_-4_5E2723.png

[23] Cheruiyor, Thomas Kimeli and Tarus, Daniel K. 2017. "Corporate Social Responsibility in Kenya: Blessing, Curse or Necessary Evil?" Pp. 169-190 in CSR, sustainability, ethics \& governance, edited by S. B. Samuel, Stephen, Vertigans. Cham. Switzerland: Springer International Publishing.

[24] Radcliff-Brown, Alfred Reginald. 1952. Structure and Function in Primitive Society. By A. R. Radcliffe-Brown, London: Cohen and West Ltd.

[25] Spencer, H. n.d. Structure, Function, and Evolution, New York: Scribner.

[26] Vincent, Joan. 2015. "Functionalism in Anthropology". International Encyclopedia of the Social \& Behavioral Sciences. https://www.sciencedirect.com/referencework/9780080970875 Accessed 12 March 2020

[27] European Commission. 2006. Implementing the partnership for growth and jobs: Making Europe a pole of excellence on corporate social responsibility Brussels: Office for Official Publications of the European Communities.

[28] Institute of Directors in Southern Africa. 2012. Report on Corporate Governance for South Africa, Parktown: King Committee on Corporate Governance.

[29] K. M. Amaeshi, B. C. Adi, C. Ogbechie, and O. Amao. "Corporate Social Responsibility (CSR) in Nigeria: Western Mimicry or Indigenous Practices?" Journal of Corporate citizenship, 24 (1): 8399, 2006.

[30] Oluduro, Olubayo. 2019. Surviving The Armageddon: The Law as Elixir for Environmental Crimes in Nigeria's Oil Industry. $14^{\text {th }}$ Inaugural Lecture Series of the Adekunle Ajasin University, Akungba, Akoko, Ondo State, Nigeria, Presented on Tuesday, $24^{\text {th }}$ September, 2019

[31] Hohnen, Paul. and Potts, Jason. (2005). Corporate Social Responsibility: An implementation guide for Canadian business, Manitoba, Canada: International Institute for Sustainable Development. https://www.unglobalcompact.org/ Accessed 15 March 2020.

[32] Chen, J. 2020. Corporate Governance Definition https://www.investopedia.com/corporate-finance-and-accounting4689821(Accessed 8 April, 2020).

[33] Moir Lance. 2001. "What do we mean by corporate social responsibility?" Corporate Governance International Journal of Business in Society 1(2): 1-19.

[34] [34] Ruangviset, Jannipa, Jiranport, Pornsit and Kim, J. C. 2014. How does CP influence CSR? Procedia Social and Behavioral Sciences, 143, 1055-1057(abridged).

[35] Kim, Dong-young and Kim, JeongYeon. 2014. "Effects of Corporate Social Responsibility and Governance on Its Credit Ratings". The scientific World Journal. Online https://doi.org/10.1155/2014/305452 Accessed 12 March, 2020.

[36] Gordon, Kathryn G. 2001. The OECD Guidelines and Other Corporate Responsibility Instruments: A Comparison. OECD Working Papers on International Investment, Publishing, Paris.

[37] ILO. 2017. "Tripartite Declaration of Principles concerning Multinational Enterprises and Social Policy", Geneva: International Labour Office. Accessed 13 April 2020 (http://www.ilo.org/publns).

[38] Hemphill, Thomas. 2013. "The ISO 26000 guidance on social responsibility international standard: what are the business governance implications?" Corporate Governance, Vol. 13 (3): $305-$ 317.

[39] United Nations, Human Rights. United Nations Guiding Principles on Business and Human Rights, 2011, Geneva: UNHR.
[40] United Nations Global Compact. 2000. The Ten Principles of the UN Global Compact. 